\title{
BMJ Open Breast cancer mortality and associated factors in São Paulo State, Brazil: an ecological analysis
}

\author{
Carmen Simone Grilo Diniz, ${ }^{1}$ Alessandra Cristina Guedes Pellini, ${ }^{2}$ \\ Adeylson Guimarães Ribeiro, ${ }^{3}$ Marcello Vannucci Tedardi, ${ }^{4}$ \\ Marina Jorge de Miranda, ${ }^{1}$ Michelle Mosna Touso, ${ }^{5}$ Oswaldo Santos Baquero, ${ }^{6}$ \\ Patrícia Carlos dos Santos, ${ }^{7}$ Francisco Chiaravalloti-Neto ${ }^{8}$
}

To cite: Diniz CSG, Pellini ACG, Ribeiro AG, et al. Breast cancer mortality and associated factors in São Paulo State, Brazil: an ecological analysis. BMJ Open 2017;7:e016395. doi:10.1136/ bmjopen-2017-016395

- Prepublication history for this paper is available online. To view these files, please visit the journal online (http://dx.doi org/10.1136/bmjopen-2017016395).

Received 10 February 2017 Revised 9 June 2017

Accepted 5 July 2017

\section{ABSTRACT}

Objective Identify the factors associated with the age-standardised breast cancer mortality rate in the municipalities of State of São Paulo (SSP), Brazil, in the period from 2006 to 2012.

Design Ecological study of the breast cancer mortality rate standardised by age, as the dependent variable, having each of the 645 municipalities in the SSP as the unit of analysis.

Settings The female resident population aged 15 years or older, by age group and municipality, in 2009 (mid-term), obtained from public dataset (Informatics Department of the Unified Health System).

Participants Women 15 years or older who died of breast cancer in the SSP were selected for the calculation of the breast cancer mortality rate, according to the municipality and age group, from 2006 to 2012.

Main outcome measures Mortality rates for each municipality calculated by the direct standardisation method, using the age structure of the population of SSP in 2009 as the standard.

Results In the final linear regression model, breast cancer mortality, in the municipal level, was directly associated with rates of nulliparity $(p<0.0001)$, mammography $(p<0.0001)$ and private healthcare $(p=0.006)$.

Conclusions The findings that mammography ratio was associated, in the municipal level, with increased mortality add to the evidence of a probable overestimation of benefits and underestimation of risks associated with this form of screening. The same paradoxical trend of increased mortality with screening was found in recent individual-level studies, indicating the need to expand informed choice for patients, primary prevention actions and individualised screening. Additional studies should be conducted to explore if there is a causality link in this association.

\section{CrossMark}

For numbered affiliations see end of article.

Correspondence to Dr Francisco Chiaravalloti-Neto; franciscochiara@usp.br

\section{INTRODUCTION}

Breast cancer is the most frequent type of cancer among women and is the second most common cancer globally, with 1.67 million new cases estimated in 2012, accounting for $25 \%$ of all cancers. Incidence rates vary by region, with higher rates in the

\section{Strengths and limitations of this study}

- This study used secondary data on breast cancer mortality and the associated covariates.

- The mortality information system used to obtain the breast cancer mortality data contains a near-complete record of deaths nationally (with comprehensive records for the State of São Paulo) and is extensive in its coverage, with only a small proportion of deaths without defined cause.

- The use of an ecological design is not aimed to assess causal relationships; however, it can be useful for raising hypothesis.

- Ecological study design can also be considered one of the strengths of this research because it allows for elucidation of invisible effects on the individual level, as overdiagnosis and overtreatment are better studied in populations, owing to the difficulties of individual-level estimation.

- The findings of this research in the aggregated level are in agreement with local recent studies with individual-level designs, also showing a positive association between mammography and breast cancer mortality.

more affluent regions: from 27 per 100000 individuals in Eastern Africa and Eastern Asia to 96 per 100000 individuals in Western Europe. $^{1}$

In 2012, breast cancer was the fifth leading cause of cancer death globally accounting for 522000 deaths. In less developed regions, where cancer mortality is proportionally smaller, breast cancer is the most frequent cause of cancer death in women $(14.3 \%$ of the total). In more developed regions, it is the second-most common cause of cancer death (15.4\% of the total), after lung cancer. ${ }^{1}$

Breast cancer is the leading cause of cancer death in women in Brazil, where there are estimated 57120 new cases annually, with an estimated incidence of 56 cases per 100000 women. However, it is the second-most 
common type of cancer that affects women in Brazil, after non-melanoma skin cancer. ${ }^{2}$ It was responsible for 14206 deaths in 2013, which represents about $16 \%$ of all cancer-related deaths among women in Brazil in that year. Between 2008 and 2013, the total number of breast cancer deaths increased by an average of $3.75 \%$ per year, in all age groups, accumulating to an increase of $20 \%$ in the period, characterising it as an important and growing public health problem. ${ }^{3}$ However, this cancer mortality in Brazil is not homogeneous, with higher rates in the most affluent regions. ${ }^{4}$

Some of the risk factors traditionally associated with a higher incidence of breast cancer include, among those considered not modifiable, the advanced age, early menarche and late-onset menopause, tall stature, high breast density and, in about $5 \%$ of cases, genetic predisposition. Reproductive factors include nulliparity, low parity, late parity, non-breast feeding and the use of hormonal contraceptives. Other risk factors include physical inactivity, exposure to ionising radiation (mammography, radiotherapy), a diet rich in processed foods and red meats, environmental factors (such as the exposure to endocrine-disrupting chemicals), obesity, alcohol consumption, shift work and hormone replacement therapy. ${ }^{5-8}$

Breast cancer incidence and mortality patterns are multifaceted, and the higher incidence among wealthier, white, educated and urban populations may reflect the association of these characteristics with those factors mentioned above. In addition to the biological mechanisms, the web of causation can vary according to the geographical region, thereby interacting with sociodemographic factors. ${ }^{78}$

In order to generate hypothesis about potential causal factors related to breast cancer mortality, the aim of this study was to identify factors associated with the age-standardised breast cancer mortality rate (per 100000 women-years) in the municipalities of São Paulo State, Brazil, from 2006 to 2012, through an ecological approach and making use of public access secondary databases.

\section{MATERIALS AND METHODS}

We chose an ecological design for its ability to synthesise an enormous set of variables and processes, in a highly complex manner, which allows for the approximation of a complete social reality. This study had the breast cancer mortality rate standardised by age as the dependent variable and each of the 645 municipalities in the State of São Paulo as the unit of analysis. On the website of the Informatics Department of the Unified Health System (DATASUS), ${ }^{9}$ the deaths by breast cancer in women 15 years of age or older across the State of São Paulo were selected for the calculation of the breast cancer mortality rate, according to the municipality and age group, from 2006 to 2012. The female resident population aged 15 years or older, by age group and municipality, in 2009 (mid-term) was obtained from DATASUS. The georeferenced maps of the municipalities of São Paulo State were obtained from the Brazilian Institute of Geography and Statistics (IBGE). ${ }^{10}$

The information about deaths and population size were used to calculate the mortality rates for each municipality by the direct standardisation method, using the age structure of the population of São Paulo State in 2009 as the standard. In order to identify possible factors associated with breast cancer deaths, the variables listed in table 1 (covariates) were selected, obtained from the IBGE, the State Data Analysis System Foundation (SEADE) and the National Regulatory Agency for Private Health Insurance and Plans (ANS), whose values were calculated for each of the municipalities of the State of São Paulo. ${ }^{11-13}$

\section{Statistical analysis}

After each of the covariates was standardised, an exploratory analysis with the standardised covariates was performed, to evaluate the presence of outliers using dot plot charts. Based on these analyses, one extreme, but correct value, was detected in the variable V_68 (per capita gross domestic product, in millions of Brazilian reais), and this problem was corrected by transformation of the variable using the square root.

The collinearity between the covariates was analysed by the variance inflation factors (VIFs) calculation. We iteratively eliminated the covariate with higher VIF, until a model with VIFs lower than 3.00 was reached. ${ }^{14}$ Among the covariates listed in table 1 , the following were selected for modelling: V_15, V_16, V_17, V_25, V_26, V_27, V_30, V_31, V_41, V_42, V_46, V_53, V_66, V_RZ_68, V_69, V_70 and V_72.

The mortality rate was modelled using multiple linear regression. For the selection of the model with the best fit, the stepwise algorithm with reverse direction was applied, and the Akaike information criterion (AIC) was used as the adjustment criterion. ${ }^{15}$ The homogeneity of the residuals was evaluated using the spread-level plot and Breusch-Pagan test. The spatial autocorrelation of the final model residuals was evaluated by the Moran's I test, ${ }^{16}$ using a neighbourhood matrix by contiguity. Residuals were also used to create scatter plot charts with predicted values, and each of the covariates (both those of the final model and those excluded), to rule out the presence of systematic patterns.

These analyses were performed in R V.3.2.3 (R Foundation for Statistical Computing $)^{17}$ and in its 'spdep' package. ${ }^{18} 19$ The maps presented were elaborated in QGIS V.2.8 (Quantum GIS development team). ${ }^{20}$

\section{RESULTS}

The breast cancer mortality rates among women aged 15 years old and over, standardised by age, for all municipalities in the State of São Paulo are shown in figure 1. The mortality rates reveal wide variation, ranging from 0 to 431.8 deaths per 100000 women-years. 
Table 1 - Explanatory variables selected for multiple linear regression analysis, São Paulo State, from 2006 to 2012

\begin{tabular}{|c|c|c|c|}
\hline Source & Variable & Category & Code \\
\hline IBGE & \multirow{3}{*}{$\begin{array}{l}\text { Distribution of population with } 18-24 \text { years } \\
\text { old by education level and municipality } \\
\text { (2010) }\end{array}$} & $\begin{array}{l}\% \text { of population } 18-24 \text { years old without education/ } \\
\text { incomplete primary education }\end{array}$ & V_15 \\
\hline IBGE & & $\begin{array}{l}\% \text { of population } 18-24 \text { years old with complete primary } \\
\text { education/incompletelower secondary education }\end{array}$ & V_16 \\
\hline IBGE & & $\begin{array}{l}\% \text { of population } 18-24 \text { years old with complete lower } \\
\text { secondary education or more }\end{array}$ & V_17 \\
\hline
\end{tabular}

IBGE Distribution of population with 15years old or more by education level and municipality IBGE (2010)

$\%$ of population 15 years old or more without education/ V_25

incomplete primary education

$\%$ of population 15years old or more with complete $\quad$ V_26 primary education/incomplete lower secondary education

IBGE

$\%$ of population 15 years old or more with complete lower secondary education or more

\begin{tabular}{|c|c|c|c|}
\hline IBGE & $\begin{array}{l}\text { Gini Index of per capita household income } \\
\text { by municipality (2010) }\end{array}$ & Gini Index & V_30 \\
\hline IBGE & $\begin{array}{l}\text { Proportion of population with low income by } \\
\text { municipality (2010) }\end{array}$ & $\%$ of population with income $<1 / 2$ minimum wage & V_31 \\
\hline IBGE & Income ratio by municipality (2010) & $\begin{array}{l}\text { Number of times the aggregate income of the top } \\
\text { quintile of the income distribution (the } 20.0 \% \text { richest) is } \\
\text { higher than the income of the lower quintile (the } 20.0 \% \\
\text { poorest) among the resident population }\end{array}$ & V_41 \\
\hline IBGE & Unemployment rate by municipality (2010) & $\begin{array}{l}\text { Unemployment rate among the population } 16 \text { years old } \\
\text { or more }\end{array}$ & V_42 \\
\hline IBGE & Illiteracy rate by municipality (2010) & Illiteracy rate among the population 15 years old or more & V_46 \\
\hline IBGE & $\begin{array}{l}\text { Proportion of elderly living in households as } \\
\text { another relative by municipality (2010) }\end{array}$ & $\%$ elderly residents as another relative & V_53 \\
\hline IBGE & $\begin{array}{l}\text { Proportion of live births of mothers with } \\
\text { seven or more prenatal consultations }\end{array}$ & $\begin{array}{l}\% \text { of live births with seven or more prenatal visits } \\
\text { (average 2009-2011) }\end{array}$ & V_70 \\
\hline IBGE & Proportion of normal births & \% of normal births (average 2009-2011) & V_72 \\
\hline IBGE & $\begin{array}{l}\text { Ratio of mammograms performed in women } \\
\text { aged } 50-69 \text { years and the female population } \\
\text { in this age group at a given place and year }\end{array}$ & Mammography ratio (average 2009-2011) & $V_{-} 73$ \\
\hline ANS & Women with private healthcare & $\begin{array}{l}\text { \% of women with private healthcare (average 2006- } \\
\text { 2012) }\end{array}$ & V_78 \\
\hline IBGE & $\begin{array}{l}\text { Women of childbearing age (10-49years old) } \\
\text { who did not have children (2010) }\end{array}$ & $\begin{array}{l}\% \text { of women in childbearing age who did not have } \\
\text { children }\end{array}$ & V_99 \\
\hline
\end{tabular}

ANS, National Regulatory Agency for Private Health Insurance and Plans; GDP, gross domestic product; IBGE, Brazilian Institute of Geography and Statistics; IDHM, Municipal Human Development Index; SEADE, State Data Analysis System Foundation.

The multiple linear regression modelling showed that the model with covariates 'Gini Index', 'Mammography ratio', 'Percentage of women with private healthcare' and 'Proportion of women of childbearing age who did not have children' produced the lowest value of AIC (6988.6). We named it as model I.

We performed the spread-level plot and Breusch-Pagan test to evaluate the homogeneity of variance of the residuals of model I and both suggested heteroscedasticity. The $\mathrm{p}$ value of Breusch-Pagan test for model I was 0.0001 .
This analysis allowed us to identify three extreme residuals and the necessity to transform the outcome. Then, we removed three municipalities that were responsible for the extreme residuals and transformed the outcome by a power of 1.8 to stabilise the spread. Doing this, both spread-level plot and Breusch-Pagan test indicated homogeneity of variance. The AIC of this new model was 12449.8. To evaluate if this new model was still that with the lowest AIC, the stepwise algorithm with reverse direction was applied again. 


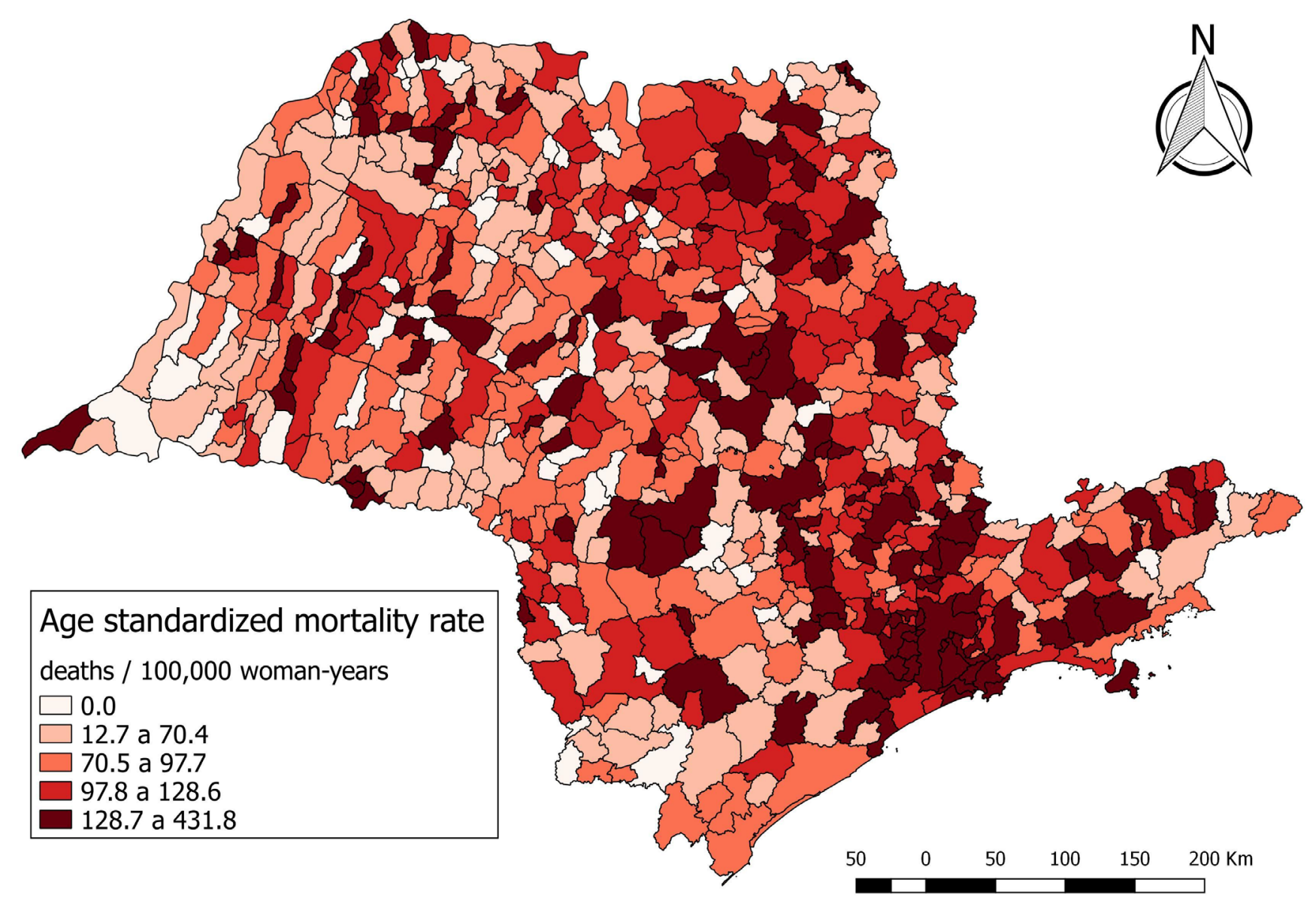

Figure 1 Map of breast cancer mortality rates (per 100000 women-years) in women 15 years and older, standardised by age, in the municipalities of São Paulo State, Brazil, in the period from 2006 to 2012.

After that and maintaining the removal of the extreme residuals and the same transformation of the outcome, we obtained the final model (model II) compounded by the covariates 'Mammography ratio', 'Percentage of women with private healthcare' and 'Proportion of women of childbearing age who did not have children'. All these covariates had a directed association with the mortality rate (table 2). The $\mathrm{R}^{2}$ of this model was $8 \%$, and the AIC was equal to 12447.8 . The spread-level plot of this model is presented in figure 2 and the Breusch-Pagan test had a $\mathrm{p}$ value of 0.3608 .

Table 2 presents the standardised covariates, according to the decreasing values of their regression coefficients (betas), that is, ordered from the highest to the lowest degree of influence on the mortality rate. The covariate 'Mammography ratio' was the most influential in breast cancer mortality. Municipalities with high breast cancer mortality rates (figure 1) would be those with high

Table 2 Standardised covariates associated with the age-standardised breast cancer mortality rate to the power of 1.8 , according to degree of influence, in São Paulo State, from 2006 to 2012 (final linear regression model (model II))

\begin{tabular}{|c|c|c|c|c|}
\hline Covariates included into the model & Estimate (Beta) & $\begin{array}{l}\text { LCL } \\
(0.025)\end{array}$ & $\begin{array}{l}\text { UCL } \\
(0.975)\end{array}$ & $\mathbf{p}$ \\
\hline Intercept & 4271.6 & 3969.2 & 4574.0 & 0.0000 \\
\hline Mammography ratio (V_73) & 801.7 & 472.6 & 1130.8 & 0.0000 \\
\hline $\begin{array}{l}\text { Proportion of women in childbearing } \\
\text { age who did not have children (V_99) }\end{array}$ & 741.4 & 378.6 & 1104.2 & 0.0000 \\
\hline $\begin{array}{l}\text { Percentage of women with private } \\
\text { healthcare }\left(V_{-} 78\right)\end{array}$ & 613.6 & 265.9 & 961.3 & 0.0006 \\
\hline
\end{tabular}

LCL, lower confidence limit; UCL, upper confidence limit. 


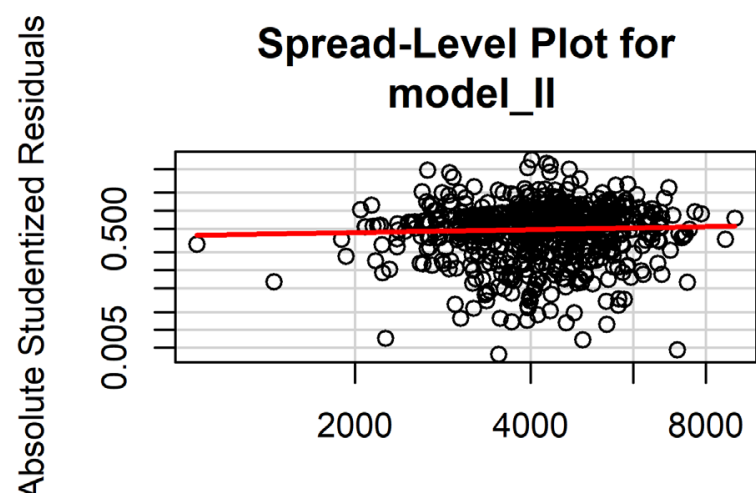

Fitted Values

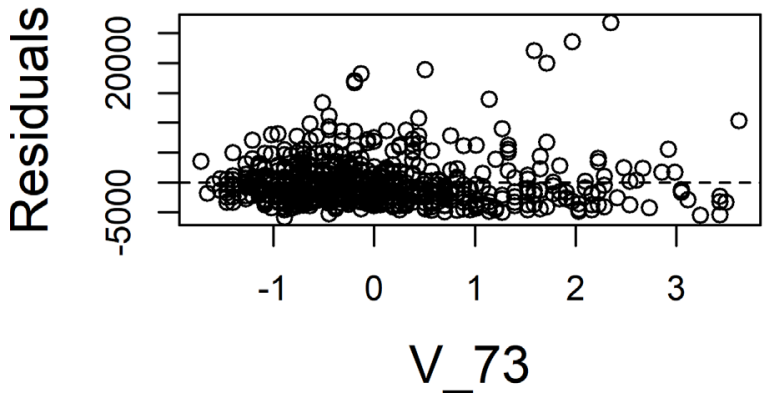

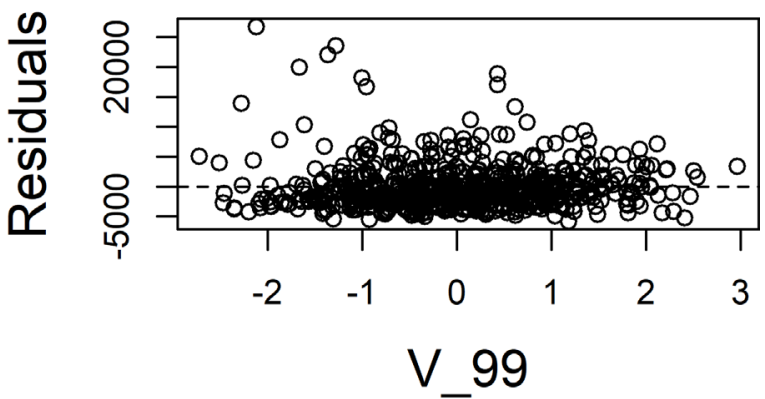

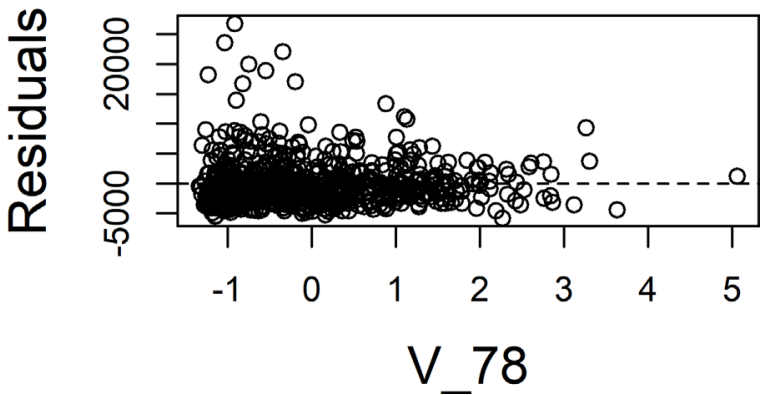

Figure 2 Spread-level plot for the final model (model II) and the scatter plots of residuals versus the covariates that entered into the final model: V_99 (Proportion of women in childbearing age who did not have children), V_73 (Mammography ratio) and V_78 (Percentage of women with private healthcare).

values of the variables associated positively with mortality from breast cancer (table 2). Table 3 shows the Pearson correlation coefficients between the covariates associated with breast cancer mortality with low collinearity $(\mathrm{VIF}<3)$.

The Moran's I of residuals of the final regression model (model II) was -0.011 , with $\mathrm{p}=0.6500$; that is, the residuals showed no spatial dependence. The scatter plots representing the residuals versus the covariates that entered into the model are presented in figure 2. These charts, as well as the scatter plots of the residuals versus the covariates that did not enter into the model, indicated no systematic patterns. The sequence of points in straight line which appears at the bottom left of the scatter plot

\begin{tabular}{|c|c|c|c|}
\hline Covariates & $v_{-} 73$ & V_78 & V_99 \\
\hline V_73: Mammography ratio & 1.00 & -0.26 & -0.38 \\
\hline $\begin{array}{l}\text { V_78: Percentage of women } \\
\text { with private healthcare }\end{array}$ & -0.26 & 1.00 & 0.49 \\
\hline $\begin{array}{l}\text { V_99: Proportion of women in } \\
\text { childbearing age who did not } \\
\text { have children }\end{array}$ & -0.38 & 0.49 & 1.00 \\
\hline
\end{tabular}

chart of residuals versus predicted values corresponds to the null values of incidence rate.

\section{DISCUSSION}

In this study, increased risk of breast cancer mortality was associated, in the municipal level, with the following factors: the mammography ratio, the proportion of women in childbearing age who did not have children (nulliparity) and the proportion of women with private healthcare.

\section{Nulliparity}

The direct relationship between breast cancer mortality and nulliparity (and never breast feeding), as found in this study, is well established in the literature. This association is explained by breast development in first pregnancy, promoting the maturation and differentiation of mammary cells, protecting against the action of carcinogenic substances. ${ }^{21-27}$

There is strong evidence of an inverse association between breast feeding and breast cancer, as shown in the extensive systematic review published by Victora $e t$ $a l .{ }^{28}$ Although a woman can breast feed without getting pregnant, and such practice is stimulated in public programmes in Brazil that promotes induced lactation 
for adoptive mothers, ${ }^{29}$ this occurrence is very exceptional. Therefore, we considered nulliparity to be a proxy for non-breastfeeding status in these women, since breastfeeding information was not available in the databases used in this research.

Every 12 months, increase in breast feeding was associated with a $4.3 \%$ reduction in the incidence of invasive breast cancer, adjusted for parity confounders. When nulliparous women were included in the model, this protection was even greater. Breast feeding also reduced the chances of diabetes, ${ }^{28}$ and may indirectly contribute to a reduced the risk of breast cancer, which is increased in diabetic women. ${ }^{30}$

In Brazil, from 1975 to 2008, the median duration of breast feeding increased from 2.5 to 11.3 months and the prevalence of exclusive breast feeding in children below 6 months old jumped from $3.1 \%$ to $41.0 \%$. $^{31}$

Likewise, studies have shown that women who had their first-term pregnancy before 18 years of age have one-third of risk for breast cancer, compared with both primigravidae over 30 years old and the nulliparous. This is because the greater the exposure to the oestrogen of ovulatory cycles, the greater the potential for genetic changes and, consequently, the development of mammary neoplasia. ${ }^{3233}$ In Brazil, poorest women tend to have children earlier, which may contribute to explain this finding. ${ }^{34}$

\section{Users of private health sector}

The direct association between higher breast cancer mortality and the proportion of women who are users of the private health sector agrees with studies about the topic published in Brazil.

Silveira ${ }^{35}$ analysed the profile of breast cancer incidence and survival, using the population-based cancer registry and the coverage of private health plans in São Paulo, comparing patients with and without health insurance. The outcomes were reported as unexpected, as the longest accumulated survival time was found among patients without health insurance. Overall mean patient survival in the 80 months of study, estimated by Kaplan-Meier, was $75.6 \%$ with a median follow-up of 41 months, with survival probabilities of $95 \%$ at 12 months and $89.1 \%$ at 60 months. Among women covered by health insurance, estimated survival rates were $93.2 \%$ in 12 months and $80.6 \%$ in 60 months, while the difference between the curves was statistically significant $(\mathrm{p}<0.001)$.

Studies in the City of São Paulo by both CEINFO ${ }^{36}$ and Girianelli $e t a l^{37}$ equally reported higher mortality among groups that made use of private sector healthcare facilities.

In a manner similar to the present study, a dissertation by Bello ${ }^{38}$ evaluated the existence of spatial dependence of female breast cancer mortality rate in the State of Rio de Janeiro over a 6-year period and concluded that 'Average income value of the main work of adults' and 'Mammographers index by municipality' were variables that had a direct association with mortality.
Other research carried out in Brazil, which studied factors related to breast cancer such as early diagnosis and survival (but not mortality), indicated that women using the private health sector had an earlier diagnosis and had a higher survival rate (the lifetime from the diagnosis to death) than users of public healthcare. Brito et $a l^{39}$ showed that women who used the public healthcare system were diagnosed about 10 years later than those who used private healthcare facilities. In a similar vein, Liedke $e t a l^{40}$ observed that women with access to private healthcare were diagnosed with cancer at an earlier stage than those in the public sector.

Having an earlier diagnosis uses to be interpreted as an advantage, based on the belief that this would necessarily have a positive effect on both morbidity and mortality. Nevertheless, as shown by several authors, ${ }^{41-44}$ survival time and mortality-to-incidence ratio (which has the number of diagnosed cases as the denominator, not the population) are inappropriate indicators to assess the impact of mammography screening on mortality, as screening may increase markedly the incidence due to diagnosis of otherwise harmless cancers that would not progress to serious illness or death. ${ }^{43} 45$

This counterintuitive finding of more access to healthcare leading to increased mortality may be explained by 'overdiagnosis' (the term used when a condition or asymptomatic disease is diagnosed but would not cause symptoms or death) and its consequences. ${ }^{46}$ The overdiagnosis of breast cancer is commonly estimated around $30 \%$, but estimates may range from $0 \%$ to over $70.0 \%$ of cases, depending on the histological type and methodology used in the study. ${ }^{42} 47$ An increased screening coverage among private healthcare users may result in higher overdiagnosis and unnecessary treatment of cases that would contribute to worse outcomes instead of improving them because they may 'result in potential years of life lost due to treatment, which is often aggressive and impacts negatively in women quality of life' ${ }^{4}$ In Brazil, screening as part of health programmes initially progressed in the private sector, but the coverage of mammography increased quickly among public sector users in recent years, approaching the target of $75.0 \%$ that was set by the Ministry of Health in the Plan of Combating Chronic Diseases for 2022. ${ }^{48}$

In private and public services, mammography screening is Brazil is basically opportunistic; the decentralised healthcare system and the lack of systematic patient documentation make it difficult to evaluate the quality of screening programmes. ${ }^{49}$

Using the private sector can be considered a proxy of having a higher income, a variable classically associated with higher breast cancer incidence and mortality, which is consistent with the international literature. ${ }^{6} \mathrm{~A}$ recent study on the spatial distribution of mortality from breast cancer in the city of São Paulo also revealed that the mortality rates are higher in more privileged groups, with the lowest mortality rates found in the less privileged socioenvironmental grouping, and a decreasing 
linear trend of rates, the worse the condition of the socioenvironmental grouping of the residence. ${ }^{36}$ Similarly, Girianelli $e t a l^{87}$ analysed data from all over Brazil and found a strong direct correlation between breast cancer mortality and positive sociodemographic indicators and inversely with the fertility rate.

Possible explanations for the finding of greater mortality due to breast cancer among the richest women are that they have greater exposure to potential carcinogens. As pointed out by Sclowitz et $a l^{50}$ these women had a higher concentration of gynaecological consultations, with greater chance of exposure to several causative factors associated with the diagnosis of breast cancer: they have more mammograms, greater use of hormonal treatments and undergo more breast biopsies. These women with higher income and education also tend to have a more advanced age at the first pregnancy and lower parity (hence, lower breastfeeding opportunities), as well as the greater use of hormonal contraceptives among these women in Brazil. ${ }^{34}$

In terms of socioeconomic and racial disparities in breast cancer incidence, in a systematic review, Vainshtein $^{51}$ concluded that socioeconomic differences are more important than racial disparities. The author suggested that future studies focus on another factor that requires particular attention, which is the disparity between racial and socioeconomic groups regarding the use of oestrogen replacement therapy (ERT), a factor already known as carcinogenic. This study also demonstrated a higher use of ERT in women with better sociodemographic indicators, white ethnicity and private healthcare sector users, which may help to explain these different incidences according to income.

Access to meat used to be associated with higher income, but in recent decades, red and processed meat intake was excessive in almost the entire population in the State of São Paulo. There was an increase in the consumption of meats in the first decade of this century, but in more recent years, red and processed meat consumption decreased in the entire population. ${ }^{52}$

\section{Mammography ratio}

In this research, mammography screening did not have a positive effect: instead, it was associated with an increase in breast cancer mortality.

Despite their widespread use, mammography screening programmes have been controversial since their emergence, and the most rigorous studies have shown no reduction in mortality. ${ }^{43}{ }^{53-56}$ A Cochrane systematic review of randomised clinical trials, updated in 2013, indicated that there was no difference in general cancer mortality between the screened and not screened populations. ${ }^{53}$

This review, as well as several recent studies, 42545758 showed high rates of false positives, additional invasive exams and the diagnosis of harmless cancers (overdiagnosis) leading to unnecessary treatment and the associated risks and harms thereof (overtreatment); all of which can result in a negative balance between harms and benefits of screening. The International Agency for Research on Cancer recently alerted that, despite the fact that some previous studies have provided evidence of the benefits of screening (substantial reduction of mortality with minor overdiagnosis), these results are not compatible with those found in randomised studies, which are considered to be a more reliable source. ${ }^{59}$

The increase in mortality among women screened by mammography can be explained by higher risks linked to both overdiagnosis and overtreatment. ${ }^{43} 5360$ The risks of diagnosis include greater exposure to ionising radiation, compression of the breast tissue, increased need for biopsies and the emotional and psychosocial risks of anxiety and depression associated with the process. ${ }^{5360}$ A report published in 2016 estimating radiation-induced cancers during screening calculated that, for every 100000 screened women aged 40-70 years old, 125 additional cancers would be induced by exam radiation, resulting in 16 deaths. ${ }^{61}$ This is very similar to the data presented by Corrêa $e t a l^{62}$ in Brazil, in the State of Goiás, estimating 16.6 annual radio-induced breast cancer deaths by 100000 women screened biannually from 40 to 70 years.

Overtreatment is the main negative consequence of overdiagnosis, which is a situation in which the patient does not receive any benefit from treatment and instead is adversely affected.$^{54}$ Treatment of breast cancer has many adverse effects that may arise from surgical complications, radiotherapy, chemotherapy and anti-oestrogen therapy. The absence of reduction in mortality, for all causes between the screened and not screened populations, has been attributed to the additional risks of treatments, which is more frequent among screened women. ${ }^{42}$

The increased risks of cardiovascular disease due to cardiac toxicity of anthracycline and trastuzumab treatment and to radiotherapy are well documented. ${ }^{63}$ The Early Breast Cancer Trialists' Collaborative Group calculated that, in women treated with radiotherapy, there was an increased relative risk of 1.78 for lung cancer deaths and of 1.27 for myocardial infarction deaths in the treated group, compared with controls. ${ }^{64}$ Baum $^{60}$ estimated that, for every 10000 screened women, for each death averted by mammography, 1-3 additional deaths by heart attack or lung cancer could be expected. Radio-induced cancer can associated to radiation from mammography ${ }^{61}$ as from radiotherapy, ${ }^{64}$ and it is possible that attribution of cause of death was biased for women with a prior diagnosis of breast cancer; for example, a woman dying of radiation induced lung or oesophageal cancer might have her condition described as breast cancer in the death certificate.

Breast cancer screening programmes by periodic mammography was created for the early detection of disease, assuming that this would reduce advanced cancer cases and, consequently, prevent mutilating surgery and mortality. ${ }^{42}$ Contrary to expectations, recent reviews have shown that screened women undergo more mutilating surgeries, compared with non-screened women. 
In mammography clinical trials, there was an increase in lumpectomies by $30 \%$ (removal of part of the breast) and in mastectomies by $20.0 \%$ (removal of the whole breast) in screened women, compared with the non-screened women. 5354

In the ecological study by Harding et $a \bar{l}^{5}$ in USA, the regions and rates of screening among more than 16.0 million women were compared, and they observed that the higher the mammography screening rate, the greater the incidence of breast cancer, with no implication on mortality reduction for this cancer. The study even showed a non-significant association between screening and the increase in breast cancer-specific mortality, in line with the results of the present study.

Screening and other medical interventions can be provided with the best intentions, but there is evidence that clinicians rarely have accurate expectations of benefits or harms of treatments, screening and tests. The inaccuracies of these expectations regard both benefits and harms, but more often, there tends to be an overestimation of benefits and underestimation of harms. ${ }^{65}$ Given the need of reliable data to inform public health, transparent surveillance of the real-life harms and benefits of programmes should be a priority in the public health research agenda.

\section{Strengths and limitations of this study}

One of the limitations of this study is the fact that secondary data on breast cancer mortality and the associated covariates were used. However, the mortality information system (Sistema de Informações de Mortalidade) contains a near-complete record of deaths nationally (with comprehensive records for the State of São Paulo) and is extensive in its coverage, with only a small proportion of deaths without defined cause (around 6.0\%). ${ }^{9}$

Another limitation is the use of an ecological design. Ecological studies are frequently used to explore possible causal relationships and to raise hypotheses, considering, as recommended by Pereira, ${ }^{66}$ that the results of the geographical comparisons from these studies lead to new investigations in which the unit of observation is the individual.

Conversely, ecological studies can address well-defined geographical areas, where global variables can be analysed comparatively, through the correlation of living conditions and health status indicators. The indicators of each area comprise averages of its total population, which is considered an integral aggregate, synthesising an enormous set of variables and processes. In this way, the aggregated studies allow to explore hypotheses in a more complex level of determination. ${ }^{67}$

Furthermore, the use of an ecological study design can also be considered to be one of the strengths of this research because it allows for elucidation of the invisible effects on the individual level, as overdiagnosis and overtreatment are better studied in populations, owing to the difficulties of estimating them at an individual level. ${ }^{47}$ The emerging evidence regarding the potential harms of screening has led to an increased interest in methodologies that can clarify the relationship between the benefits and the harms of mammography, considering the particularities of each context. ${ }^{4758}$ Another strength is the fact that findings in the aggregate level are lined up with the results of recent studies with individual-level designs, as presented above. ${ }^{35} 3638$

Therefore, this research reinforces the importance of disseminating accurate information for patients in a manner in which they can make an informed choice based on robust evidence regarding both the potential harms and benefits of screening. In developed countries, programmes to both 'translate' this information in a userfriendly way (known as 'risk literacy') and update health professionals for a more realistic view of such risks and benefits are already being organised. ${ }^{68} 69$ Alerting women about the ill effects of overdiagnosis is an ethical responsibility of health providers and policy-makers. ${ }^{70}$

\section{CONCLUSIONS AND RECOMMENDATIONS}

In the present study, breast cancer mortality was directly associated, in the municipal level, with mammography ratio, nulliparity and private healthcare. These findings, especially the association between mammography ratio and increased mortality, reinforce results of previous research on the probable overestimation of benefits and underestimation of risks associated with this type of screening and heighten the urgency of updating breast cancer prevention programmes. Additional studies should be conducted to explore potential causality link in these associations. In any case, this indicates the need to expand primary prevention actions and individualised screening, including breast awareness, informed choice and health literacy resources for women, as well as the need for innovative approaches to monitor both positive and negative outcomes of public health programmes. ${ }^{47}$

\section{Author affiliations}

1Departamento de Saúde, Ciclos de Vida e Sociedade da Faculdade de Saúde Pública, Universidade de São Paulo, São Paulo, Brazil

${ }^{2}$ Centro de Vigilância Epidemiológica "Prof. Alexandre Vranjac", Secretaria de Estado da Saúde de São Paulo, São Paulo, Brazil

${ }^{3}$ Departamento de Saúde Ambiental, Faculdade de Saúde Pública, Universidade de São Paulo, São Paulo, Brazil

${ }^{4}$ Departamento de Patologia, Faculdade de Medicina Veterinária e Zootecnia, Universidade de São Paulo, São Paulo, Brazil

${ }^{5}$ Departamento de Enfermagem Materno-Infantil e Saúde Pública, Escola de Enfermagem de Ribeirão Preto, Universidade de São Paulo, São Paulo, Brazil ${ }^{6}$ Departamento de Medicina Veterinária Preventiva, Faculdade de Medicina Veterinária e Zootecnia, Universidade de São Paulo, São Paulo, Brazil

${ }^{7}$ Secretaria Municipal de Saúde de São Paulo, Coordenação de Epidemiologia e Informação, São Paulo, Brazil

${ }^{8}$ Departamento Epidemiologia, Faculdade de Saúde Pública, Universidade de São Paulo, São Paulo, Brazil

Contributors Conception and design of study: CSGD, ACGP, MJM, OSB and FCN; acquisition of data: ACGP, MVT, MJM, MMT and PCS; analysis and/or interpretation of data: CSGD, ACGP, AGR, MVT, MJM, MMT, OSB, PCS and FCN; drafting the manuscript: CSGD, ACGP, AGR, OSB and FCN; revising the manuscript critically for important intellectual content: CSGD, ACGP, AGR, MMT, OSB and FCN. All authors approved of the version of the manuscript to be published. 
Competing interests None declared.

Ethics approval The study did not obtain the approval of Ethics Committee because the used data (about the breast cancer mortality and about the covariates) were obtained from public datasets that are open for the access of everyone.

Provenance and peer review Not commissioned; externally peer reviewed.

Data sharing statement № additional data are available.

Open Access This is an Open Access article distributed in accordance with the Creative Commons Attribution Non Commercial (CC BY-NC 4.0) license, which permits others to distribute, remix, adapt, build upon this work non-commercially, and license their derivative works on different terms, provided the original work is properly cited and the use is non-commercial. See: http://creativecommons.org/ licenses/by-nc/4.0/

(c) Article author(s) (or their employer(s) unless otherwise stated in the text of the article) 2017. All rights reserved. No commercial use is permitted unless otherwise expressly granted.

\section{REFERENCES}

1. Ferlay J, Soerjomataram I, Dikshit R, et al. Cancer incidence and mortality worldwide: sources, methods and major patterns in GLOBOCAN 2012. Int J Cancer 2015;136:E359-E386.

2. Instituto Nacional de Câncer José Alencar Gomes Da Silva. Estimativa 2014: incidência de câncer no Brasil. Rio de Janeiro, 2014.

3. Observatório de Oncologia. Dados e fatos sobre o câncer de mama 2015. http://observatoriodeoncologia.com.br/dados-e-fatos-sobreo-cancer-de-mama/ (cited 2016 Jun 8)

4 Martins CA, Guimarães RM, Silva R, et al. Evolução Da Mortalidade por câncer de mama em Mulheres Jovens: desafios Para Uma política de Atenção Oncológica. Rev Bras Cancerol 2013;59:341-9.

5. Inumaru LE, Da SEA, Naves MMV. Risk and protective factors for breast cancer: a systematic review. Cad saúde pública / Ministério da Saúde, Fundação Oswaldo Cruz, Esc Nac Saúde Pública 2011;27:1259-70.

6. Anothaisintawee T, Wiratkapun C, Lerdsitthichai P, et al. Risk factors of breast cancer: a systematic review and meta-analysis. Asia-Pacific J Public Heal 2013:25:368-87.

7 Schettler T. The ecology of breast cancer: Science \& Environmenta Health Network, 2013.

8. Vineis P, Wild CP. Global cancer patterns: causes and prevention. Lancet 2014;383:549-57.

9. Ministério da Sáude B. Datasus [Internet]. Informações de Saúde. 2015. http://www.datasus.gov.br/ (cited 2015 Mar 15).

10. IBGE. Instituto Brasileiro de Geografia e Estatística. Geociências - malhas digitais - municípios 2014 - SP [Internet]. 2014. http:// downloads.ibge.gov.br/downloads_geociencias.htm (cited 2015 Aug 16).

11. IBGE. Instituto Brasileiro de Geografia e Estatística. Censo 2010 [Internet]. 2010. http://censo2010.ibge.gov.br/ (cited 2015 Jun 1)

12. Brasil E de SP. SEADE - Fundação Sistema Estadual de Análise de Dados [Internet]. 2015. http://www.seade.gov.br/ (cited 2015 Jun 1).

13. Ministério da Sáude B. ANS - Agência Nacional de Saúde Suplementar [Internet]. 2015. http://www.ans.gov.br/ (cited 2015 Aug 16).

14. Zuur AF, leno EN, Elphick CS. A protocol for data exploration to avoid common statistical problems. Methods Ecol Evol 2010;1:3-14.

15. MacKenzie DI, Bailey LL. Assessing the fit of site-occupancy models $J$ Agric Biol Environ Stat 2004:9:300-18.

16 Bivand RS, Pebesma E, Gómez-Rubio V, et al. Applied spatial data analysis with R. New York: Second Springer editor, 2013:405.

17 Core Team R. R: a language and environment for statistical computing. Vienna, Austria: R Foundation for Statistical Computing, 2015. https://www.r-project.org/

18. Bivand R, Hauke J, Kossowski T. Computing the Jacobian in Gaussian spatial autoregressive models: an Illustrated comparison of available methods. Geogr Anal 2013;45:150-79.

19. Bivand R, Piras G. Comparing implementations of estimation methods for spatial econometrics. J Stat Softw 2015;63:1-36.

20. QGIS Development Team. QGIS Geographic Information System [Internet]. OpenSource Geospatial Foundation Project. 2015. http:// qgis.osgeo.org

21. Instituto Nacional de Câncer José Alencar Gomes da Silva. Estimativa 2012: incidênciade câncer no Brasil: Rio de Janeiro, 2011.

22. Rea MF. Os benefícios da amamentação para a saúde da mulher. Pediatr 2004;80:142-6.
23. Boff $A$, Schappo CR, Kolhs M. Câncer de mama: perfil demográfico e fatores de risco. $R$ Saúde Públ St Cat 2010;3:21-31.

24. Batiston AP, Tamaki EM, De SLA, et al. Knowledge of and practices regarding risk factors for breast cancer in women aged between 40 and 69 years. Rev Bras Saúde Matern Infant 2011;11:163-71.

25. de Souza MM, Winnikow EP, Moretti GP, et al. De A. Taxa de mortalidade por neoplasia maligna de mama em mulheres residentes Da Região Carbonífera Catarinense no período de 1980 a 2009. Cad Saúde Coletiva 2013;21:384-90.

26. Simeão SF, Landro ICR, De Conti MHS, et al. Qualidade de vida em grupos de mulheres acometidas de câncer de mama. Cien Saude Colet 2013;18:779-88.

27. Rodríguez CC, Biset AED, Mayeta YB, et al. Factores de riesgo de cáncer de mama enmujeres pertenecientes a un consultorio médico del Centro Urbano “José Martí.”. MEDISAN 2013;17:4089-95.

28. Victora CG, Bahl R, Barros AJ, et al. Lancet Breastfeeding Series Group. Breastfeeding in the 21st century: epidemiology, mechanisms, and lifelong effect. Lancet 2016;387:475-90.

29. de Almeida JAG, Novak FR. Amamentação: um híbrido naturezacultura. J Pediatr 2004:8025:119.

30. Larsson SC, Mantzoros CS, Wolk A. Diabetes mellitus and risk of breast cancer: a meta-analysis. Int J Cancer 2007;121:856-62.

31. Venancio SI, Saldiva S, Monteiro CA, et al. Secular trends in breastfeeding in Brazil. Rev Saude Publica 2013;47:1-4.

32 Gradim CVC, Magalhães MC, Faria M de CF, et al. Aleitamento materno como fator de proteção para o câncer de mama. Rev Rene 2011;12:358-64.

33. Ritte R, Tikk K, Lukanova A, et al. Reproductive factors and risk of hormone receptor positive and negative breast cancer: a cohort study. BMC Cancer 2013;13:584

34. Ministério da Sáude B. PNDS 2006: Pesquisa Nacional de Demografia e Saúde da Criança e da Mulher: relatório. Brasília, 2008

35. Silveira DP. Perfil Da incidência e da sobrevida de câncer de mama: análise a partir dos registros de câncer de base populacional e cobertura de planos privados de saúde no município de São Paulo . Escola Nacional de Saúde Pública Sergio Arouca. 2011. http://bvssp. icict.fiocruz.br/lildbi/docsonline/get.php?id=2739

36. CElnfo C de E e I-. Mortalidade por câncer de mama e de colo uterino: estudo da distribuição espacial no município de São Paulo. São Paulo, 2014

37. Girianelli VR, Gamarra CJ, Azevedo e Silva G. Disparities in cervical and breast cancer mortality in Brazil. Rev Saude Publica 2014;48:459-67.

38. Bello MA. Análise estatística espacial da mortalidade por câncer de mama feminina no estado do Rio de JaneiroDissertação. Rio de Janeiro: Escola Nacional de Saúde Pública Sergio Arouca, 2010.

39. Brito C, Portela MC, Vasconcellos MTLde. Sobrevida de mulheres tratadas por câncer de mama no estado do Rio de Janeiro. Rev Saude Publica 2009;43:481-9.

40. Liedke PE, Finkelstein DM, Szymonifka J, et al. Outcomes of breast cancer in Brazil related to health care coverage: a retrospective cohort study. Cancer Epidemiol Biomarkers Prev 2014;23:126-33.

41. Schmidt $H$. The ethics of incentivizing mammography screening. JAMA 2015;314:995-6.

42. Løberg M, Lousdal ML, Bretthauer M, et al. Benefits and harms of mammography screening. Breast Cancer Res 2015;17:63.

43. Gigerenzer $\mathrm{G}$. Full disclosure about cancer screening. BMJ 2016;352:h6967-2..

44. Prasad V, Lenzer J, Newman DH. Why cancer screening has never been shown to "save lives"--and what we can do about it. BMJ 2016;352:h6080.

45 Narod SA, lqbal J, Miller AB. Why have breast cancer mortality rates declined? J Cancer Policy 2015;5:8-17. Elsevier Ltd.

46. Welch HG, Black WC. Overdiagnosis in cancer. J Natl Cancer Inst 2010;102:605-13.

47. Carter JL, Coletti RJ, Harris RP. Quantifying and monitoring overdiagnosis in cancer screening: a systematic review of methods. BMJ 2015;350:g7773

48. Malta DC, Bernal RT, Oliveira M. Trends in risk factors chronic diseases, according of health insurance, Brazil, 2008-2013. Cien Saude Colet 2015;20:1005-16.

49. Silva TB, Mauad EC, Carvalho AL, et al. Difficulties in implementing an organized screening program for breast cancer in Brazil with emphasis on diagnostic methods. Rural Remote Health 2013;13:2321.

50. Sclowitz ML, Menezes AMB, Gigante DP, et al. Condutas na prevenção secundária do câncer de mama e fatores associados. Rev Saude Publica 2005;39:340-9.

51. Vainshtein J. Disparities in breast Cancer incidence across racial/ ethnic strata and socioeconomic status: a systematic review. J Nat Med Assoc 2008;100:833-9. 
52. de Carvalho AM, César CL, Fisberg RM, et al. Meat consumption in São Paulo-Brazil: trend in the last decade. PLoS One 2014;9:e96667.

53. Gøtzsche PC, Jørgensen KJ. Screening for breast cancer with mammography. Cochrane Database Syst Rev 2013:CD001877.

54. Keen JD, Jørgensen KJ. Four principles to consider before advising women on screening mammography. J Womens Health 2015;24:867-74.

55. Bleyer A, Baines C, Miller AB. Impact of screening mammography on breast cancer mortality. Int J Cancer 2016;138:2003-12.

56. Mukherjee S. The emperor of all maladies: a biography of cancer. New York: Scribner, 2011.

57. Gøtzsche PC. Mammography screening is harmful and should be abandoned. J R Soc Med 2015;108:341-5.

58. Harding C, Pompei F, Burmistrov D, et al. Breast Cancer Screening, Incidence, and Mortality Across US Counties. JAMA Intern Med 2015;175:1483-9.

59. Lauby-Secretan B, Scoccianti C, Loomis D, et al. Breast-Cancer Screening - Viewpoint of the IARC Working Group. N Engl J Med Overseas Ed 2015;372:2353-8.

60. Baum M. Harms from breast cancer screening outweigh benefits if death caused by treatment is included. BMJ 2013;346:f385-2.

61. Miglioretti DL, Lange J, van den Broek JJ, et al. Radiation-Induced breast cancer incidence and mortality from Digital mammography screening: a modeling study. Ann Intern Med 2016;164:205-14.
62 Corrêa R da S, Peixoto JE, Ferreira RDS, et al. Risco de câncer radioinduzido em rastreamento mamográfico. Rio de Janeiro, RJ, Brazil: IX Latin American IRPA Regional Congress on Radiation Protection and Safety - IRPA 2013, 2013. http://www.iaea.org/inis/ collection/NCLCollectionStore/_Public/45/071/45071081.pdf

63. Valachis A, Nilsson C. Cardiac risk in the treatment of breast cancer: assessment and management. Breast Cancer 2015;7:21-35.

64 Clarke M, Collins R, Darby S, et al. Effects of radiotherapy and of differences in the extent of surgery for early breast cancer on local recurrence and 15-year survival: an overview of the randomised trials. Lancet 2005;366:2087-106.

65. Hoffmann TC, Del Mar C. Clinicians' expectations of the benefits and harms of treatments, screening, and tests: a systematic review. JAMA Intern Med 2017;177:407.

66. Pereira MG. Epidemiologia - Teoria e Prática. Rio de Janeiro: Guanabara Koogan, 2002:596.

67. Rouquayrol MZ, Filho N de A. Epidemiologia \& Saúde. Rio de Janeiro: MEDSI, 1999:600.

68. Gigerenzer G. Breast cancer screening pamphlets mislead women. BMJ 2014;348:g2636-2.

69. Brennan M, Houssami N. Discussing the benefits and harms of screening mammography. Maturitas 2016;92:150-3.

70. Hersch J, Barratt A, Jansen J, et al. The importance of enabling informed decision making for women considering breast cancer screening. J Med Screen 2016;23:55 